\title{
Ecological Roles of Benthic Community in Seafloor Northwards of Pulau Indah, Klang, Malaysia
}

\author{
Mohd Sophian Mohd Kasihmuddin* and Zaidi Che Cob \\ Department of Earth Sciences and Environment, Faculty of Science and Technology, Universiti Kebangsaan \\ Malaysia, 43600 UKM, Bangi, Selangor
}

\begin{abstract}
Trait assessment is an alternative but effective method of biomonitoring benthic community in ecosystem, but it was rarely done in Malaysia. An assessment was done to identify the dominant sub-traits, or modalities, within benthic community in seafloor northwards of Pulau Indah, Klang, Malaysia, and to establish possible correlation between modalities with environmental parameters measured in the area. Sampling was conducted in November 2018, during Northwest Monsoon season. Sediments were obtained by using a Ponar Grab and filtered through $500 \mu \mathrm{m}$ sieve. Sediments were subjected into Loss of Ignition method to extract organic carbon, and filtration method to determine particle size distribution percentages. 37 taxa were recorded in this study, totalling to 848 individuals. Traits assessment indicated vermiform body shape, direct larval development, deposit feeder, non-motile, asexual reproduction, and second-order opportunistic group as most dominant modalities in the study area. Station 1 recorded highest macrobenthos density (21000 ind./m2), while station 5 recorded highest diversity $\left(H^{\prime}=2.19\right)$. Functional diversity $(F D)$ for reproduction method was highest in station $1(F D=0.61)$, ecological group in station $4(F D=0.73)$; body shape $(F D=0.56)$ and larval development $(F D=0.63)$ in station 5 , and lastly, adult mobility $(F D=0.70)$ and feeding mode $(F D=0.66)$ in station 6. Principal component analysis showed Station 1 has most modalities attributed towards it. Pearson correlation analysis suggested particle size distribution as major connector for most modalities $(P=0.05)$. As BTA study is still

ARTICLE INFO

Article history:

Received: 03 December 2020

Accepted: 05 February 2021

Published: 30 April 2021

DOI: https://doi.org/10.47836/pjst.29.2.31

E-mail addresses:

sophianmkmaidin@gmail.com (Mohd Sophian Mohd

Kasihmuddin)

zdcc@ukm.edu.my (Zaidi Che Cob)

* Corresponding author new in Malaysian waters, it could serve as a good starting point for future assessment related to ecological functioning of benthic community in Malaysian seafloor.

Keywords: Biological traits analysis, ecosystem monitoring, macrobenthos, modalities, polychaete, traits
\end{abstract}




\section{INTRODUCTION}

Benthic community distributes very differently across the seafloor of the world (Lomovasky et al., 2011). This variation occurs due to the nature of the benthos themselves. Characteristic of the benthic organisms can define what they are capable of, and how they respond to changes in the environment, as well as how do they engage on forage and procreation (Hou et al., 2020; Widdows et al., 2000). These, known as traits, are unique and only found in certain group of taxa (Verberk et al., 2013). Taxa from higher hierarchy taxonomy may possess similar traits, but lower taxonomic level taxon may display different traits.

Traits found in available taxa could serve as a useful tool to understand the nature of the biotope taxa is found in better perspective (Zhong et al., 2018). Unique traits displayed by the taxa can denote their role toward the ecosystem. Traits shown in taxa denote their feeding mode, territoriality, and reproductive strategy (Zhong et al., 2018). Benthic community depends heavily on the seafloor habitat and does not have effective displacement method to migrate to another seafloor region. Depending on localities and existing environmental factors, diversity of traits shown at the seafloor biotope may vary. Study by Paganelli et al. (2012) on the connection between existing traits in benthic community with their habitat's distance to the coastline of Emilia-Romagna, Italy, found majority of taxa in nearshore $(\sim 3 \mathrm{~km})$ area was dominated by mobile vermiform organisms with tube-dwelling and deposit-feeding behavior. However, further off the coastline $(<$ $10 \mathrm{~km}$ ), the dominant taxa were either laterally compressed or globose body shape, and majority of them possess deposit-feeding and filter-feeding as dominant traits in terms of feeding behavior.

Trait assessment has become increasingly popular, but it has rarely been done in Malaysian waters (Hanamura et al., 2008; Hussin, 2014). This is because identifying the traits can be time-constraining, and details of targeted taxa can be very vague due to the lack of accurate reference about the benthic taxa (Korte \& Ashley, 2013). Most of ecological assessments done in biodiversity in Malaysian waters were conducted in traditional approaches via identifying inhabiting taxa in-site but may or may not disregard important factor behind the taxa such as origin of taxa (nature vs. invasive), feeding behaviour, and body shape.

Resultant observation on traits from taxa can be further applied on discerning correlation between governing traits with surrounding area. Known as Biological Traits Analysis (BTA), this analysis aims to establish connection between traits, taxa, and the surrounding environment (Linden et al., 2012). BTA requires compilation of sub-traits within traits in form of matrices, followed by ordination analysis such as Fuzzy Correspondence Analysis (FCA) or Principal Component Analysis (PCA) (Dell et al., 2011). These sub-traits can further be interpreted by ecological mean as direct influence toward the related taxa, and ultimately, the taxon's influence toward or by corresponding environment (Xu et al., 2018). 
Bolam et al. (2016) undertook BTA assessment towards benthic community in a licensed disposal dredged material site in northeast coast of England. Their assessment indicated significant differences between site affected by dredged material fluxes and nonaffected site over four years period, where constant influx of dredged materials reduces free-living and predator traits over time. Both traits were associated with complex taxa such as crustaceans, errant polychaetes, ophiuroids, and sea star, where their larger body size and enhanced mobility may enable them to escape from burial by dredged materials. Conversely, influx of dredged materials showed increased taxa capable of performing bioturbation across sediment such as bivalves, gastropods, and sedentary polychaetes. BTA assessments showed large flexibility in terms of interpretation of data, thus this makes a very suitable assessment for various studies regarding ecological issues. Unfortunately, BTA assessment was rarely done in Malaysian waters. All ecological studies towards benthic community in Malaysian waters are all rather assessed via traditional means, through assessing the number of members on each taxon. BTA can be very useful ecological tool to understand the current state of benthic community in Malaysian waters effectively.

This study intends to focus on identifying dominant traits within taxa found in benthic community in various point of seafloor northwards of Pulau Indah, one of the busiest industrial areas in Klang Valley. The findings from these assessments can be applied further for studies related to ecology such as assessing invasive species in enclosed water (Gergs \& Rothhaupt, 2015), impact of environmental stressors to environmentally sensitive benthic community over time (Bolam et al., 2017) and genetic drifts for migration of certain organisms over time (Padron \& Guizien, 2016). Therefore, the objective of this study is to establish list of traits attributed by available taxa in benthic community inhabiting seafloor in waters northwards of Pulau Indah, Klang, and to assess Biological Trait Analysis of benthic community in the area.

\section{MATERIALS AND METHODS}

\section{Procurement of Benthic Specimens and Sediments}

The sampling took place in waters northwards of Pulau Indah, Klang. Pulau Indah is an island bustled with industrial plants and human settlements (Figure 1). It is located nearby mangrove island Pulau Ketam, and within waterways connecting important ports such as West Port, North Port and Southpoint. It is also connected with multiple point sources from inland river outflows such as Sungai Klang and Sungai Langat. During the sampling session, sediment samples were acquired by using a Ponar Grab with $0.023 \mathrm{~m}^{2}$ mouth area. The salinity and water depth were measured by using a salinometer and a digital depth sounder respectively. Sediment samples were taken for taxa identification and another samples for sediment characteristic analysis. For taxa identification part, the sediment samples were sieved through a $500 \mu \mathrm{m}$ sieve to obtain the macrobenthic specimen. 
Specimens were sorted in laboratory and stored in containers with 70\% ethanol for taxa identification. As for sediment analysis, samples were subjected into Total Organic Carbon (TOC) and Particle Size Distribution assessment via Loss of Ignition (LOI) method and filtration method, respectively.

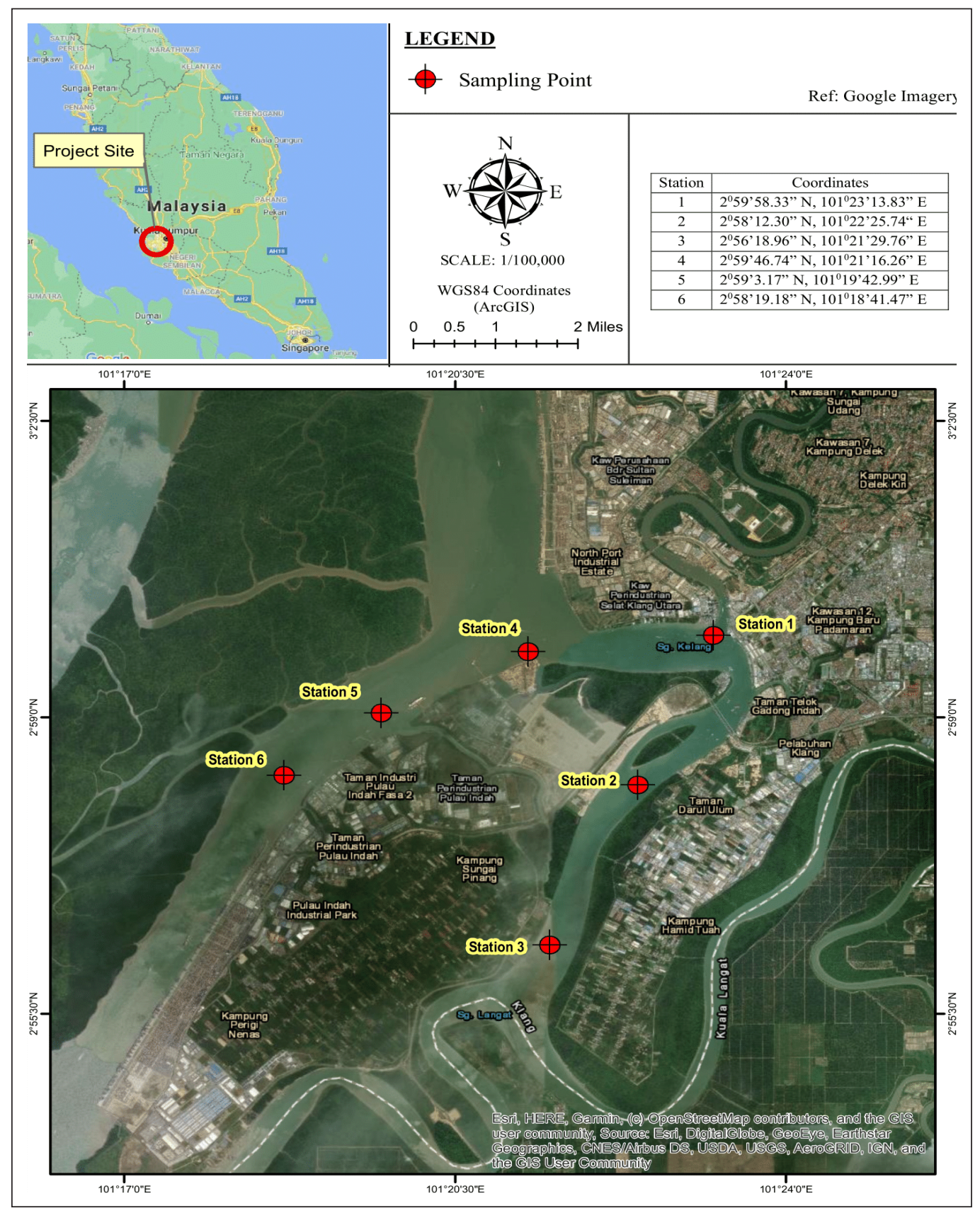

Figure 1. Location of sampling areas in this study 


\section{Assessment of Taxa and Their Respective Traits}

Macrobenthos specimens were identified to the lowest taxonomic level as possible, preferably genera or species. As for traits assessment, each taxon was classified based on the following traits: body shape, feeding mode, adult mobility, reproductive technique, larval development, and ecological group (Table 1). These modalities or sub-traits were useful to define traits more accurately in terms of their biological and ecological characteristics and their possible role towards ecosystem they inhabit. In this stage, all taxa were compiled into a master list in which each taxon were matched to their corresponding sub-traits. Identification of each taxon and their respective traits were done based on checklist, database, and key descriptions from selected references such as Baharuddin et al. (2018), Fauchald (1977), Faulwetter et al. (2017), Fujita and Irimura (2015), Idris

Table 1

List of traits and modalities used in this study

\begin{tabular}{|c|c|c|}
\hline Traits & Modalities & Label \\
\hline \multirow[t]{4}{*}{ Body Shape } & Dorso-Ventral Compressed & DvC \\
\hline & Laterally Compressed & LtC \\
\hline & Globose & Gb \\
\hline & Vermiform & $\mathbf{V f}$ \\
\hline \multirow[t]{5}{*}{ Feeding Mode } & Filter Feeder & FIFd \\
\hline & Carnivore/Omnivore & $\mathrm{CrOm}$ \\
\hline & Surface-Deposit Feeder & SDFr \\
\hline & Sub Surface-Deposit Feeder & SSDFr \\
\hline & Scavenger & $\mathrm{ScV}$ \\
\hline \multirow[t]{5}{*}{ Adult Mobility } & Swimmer & Sw \\
\hline & Burrower & Bw \\
\hline & Crawler & $\mathbf{C w}$ \\
\hline & Walker & Wk \\
\hline & Non-Motile/Semi Motile & $\mathbf{n M}$ \\
\hline \multirow[t]{3}{*}{ Reproductive Technique } & Asexual & Asex \\
\hline & Sexual, Gonocoric & Sex_G \\
\hline & Sexual, Heramphrodite & Sex_H \\
\hline \multirow[t]{4}{*}{ Larval Development } & Planktontrophic & PI \\
\hline & Lecitotrophic & Le \\
\hline & Direct Development & DD \\
\hline & Brooding & $\mathrm{Br}$ \\
\hline \multirow[t]{5}{*}{ Ecological Group (AMBI) } & Sensitive & I \\
\hline & Indifferent & II \\
\hline & Tolerant & III \\
\hline & Second Order Opportunistic & IV \\
\hline & First Order Opportunistic & $\mathbf{V}$ \\
\hline
\end{tabular}


and Arshad (2013), Mikac (2015), Ng and Davie (2002) and Ong and Wong (2015) and online databases such as Polytrait, Animal Diversity (ADW) and World Register of Marine Species (WoRMS).

Trait assessment was done via fuzzy coding, in which each taxon was given a score based on its affinity to the sub-traits. Score 0 represents no affinity, score 1 represents low affinity, score 2 represents high affinity, and score 3 represents absolute affinity (exclusive) towards the sub-trait. The purpose of this coding is to exhibit degrees of variations and diversity within targeted benthic community in the region (Paganelli et al., 2012).

Determination of Ecological Indices and Functional Diversity

In this study, the following ecological indices were used: Shannon-Wiener Index $\left(H^{\prime}\right)$, Pielou's Index $\left(J^{\prime}\right)$, Simpson Index $(D)$ and Margalef Richness Index $\left(D_{m g}\right)$. $H^{\prime}$ was used to assess diversity of benthic taxa in station, $J$ ' for assessing evenness, $D$ for taxon's dominance in the region, and $D_{m g}$ for assessing taxa richness (Equation 1, 2, 3, \& 4).

Shannon-Wiener Index, $H^{\prime}=-\sum \frac{n_{i}}{n} \ln \left(\frac{n_{i}}{n}\right)$

Pielou's Index, $J^{\prime}=\frac{H^{\prime}}{H_{\max }}$

Simpson Index, $D=\sum\left(\frac{n_{i}}{n}\right)^{2}$

Margalef Richness Index, $D_{m g}=\frac{(S-1)}{\ln N}$

$n_{i}$ denoted individual number for a taxon $i, H_{\max }$ denoted maximum diversity in the region and $S$ denoted number of taxa in the region.

Rao's quadratic entropy was used to measure functional diversity of benthic communities based on traits assessed in this study. Rao's quadratic entropy calculates Functional Diversity $(F D)$ based on taxa abundance and traits gathered in 'Taxa by Station' matrix. Excel's macro feature 'FunctDiv.xls' (https://botanika.prf.jcu.cz/suspa/FunctDiv. php) Lepš et al. (2006) was used to obtain the functional diversity for each station. Record of functional diversity (FD) for traits in each station was calculated via Excel macro file developed by Lepš et al. (2006) and shown in Table 4.

\section{Statistical Analysis and Biological Traits Analysis (BTA)}

Datasets from the physical parameters, ecological indices and functional diversity were subjected with one-way ANOVA test to identify differences between stations. Pearson 
Correlation Analysis was performed on the 'Traits by Station' matrix to identify possible correlation between sub-traits of each trait toward the physical parameters.

To initiate BTA, two matrices were used i.e., 'Taxa by Station' matrix and 'Taxa by Trait' matrix. 'Taxa by Station' matrix comprised of taxa with individual numbers, while 'Taxa by Traits' matrix comprised of biological traits for each taxon found in the entirety of this study, derived from the fuzzy-coded database as mentioned previously. Both matrices were then combined to form 'Trait by Station' matrix, whereby denotes biological traits found in each station. The 'Trait by Station' matrix was used further for BTA analysis in form of ordination using Principal Component Analysis (PCA), to determine which subtraits are associated with the stations. In this study, PAST 4.03 was used to assess one-way ANOVA test and PCA, whilst SPSS 1.0.0.1406 was used to assess Pearson Correlation Analysis.

\section{RESULTS AND DISCUSSIONS}

\section{Assessment of Taxa and their Respective Traits}

A total of 848 macrobenthos individuals were enumerated, with station 1 recorded the highest abundance $(n=483)$ whilst station 4 recorded the lowest $(n=25)$. In terms of phyla, the Annelida recorded the highest abundance $(n=789)$, followed by Arthropoda $(n=15)$, Echinodermata $(n=12)$ and Mollusca $(n=32)$. Thirty seven (37) taxa were found in this study (Table 2), with phylum Annelida accounted as the highest taxa count than other phyla $(n=23)$. In terms of taxa count at each station, Station 1 recorded the highest taxa count $(n=11)$, while station 4 recorded the lowest $(n=8)$.

In terms of trait assessment, the modality vermiform (Vf) from body shape and direct development (DD) from larval development recorded the highest in all stations (Figure 2). Majority of taxa members in Phylum Annelida possess vermiform body shape in adult stage, as seen in all polychaete taxa found in this study (Fauchald, 1997; Mikac, 2015). Previous records for BTA analysis in Emilia-Romagna coast, Italy reported the dominance of vermiform trait amongst other body shape modality due to large numbers of polychaetes at coastline and intertidal zone (Pagenelli et al., 2012). Based on information gathered from Polytrait and ADW database, most Sedentaria polychaetes such as Capitellids, Cirratulids and Spionids undergo direct development growth instead of usual multiple growth stages like Errantia polychaetes (Faulwetter et al., 2017). Higher percentage of direct development modality in this study was highly attributed to dominance of these Sedentarian polychaetes throughout the stations, which are very common in sediment closer to estuaries (Guan et al. 2014; Mohamamad \& Jalal, 2018).

In terms of feeding mode trait, sub-surface deposit feeder (SSDFr) modality was the highest in station 1 to 3 , while surface deposit feeder (SDFr) modality was the highest in the next three stations. Like body shape and larval development trait, Sedentarian polychaetes 
Table 2

Taxa recorded in seafloor of Pulau Indah, Klang

\begin{tabular}{|c|c|c|c|c|c|c|}
\hline & St1 & St2 & St3 & St4 & St5 & St6 \\
\hline Alvania & & & 7 & & & \\
\hline Ancistrosyllis & & 7 & & & & \\
\hline Capitella & 4 & & & & & \\
\hline Caulleriella & 83 & 98 & & & & 4 \\
\hline Cerithidea rhizophorarum & 5 & & 5 & & & \\
\hline Cerithidea rhizophorarum morchii (var.) & 8 & & 2 & & & \\
\hline Cerithium & & 4 & & & & \\
\hline Cirriformia & 130 & 43 & & & & \\
\hline Cossura & & & & & & 1 \\
\hline Eunice & & 2 & 3 & & & \\
\hline Eurythoe & & & & & 1 & \\
\hline Flabellina & 1 & & & & & \\
\hline Glycera & & & & 2 & 4 & 6 \\
\hline Goniada & & & & 4 & 5 & \\
\hline Maldanidae. & & & 2 & 1 & 2 & \\
\hline Mediomastus & 82 & & 11 & & & \\
\hline Micronepthys & 9 & & & 3 & & \\
\hline Micropanope spinipes & & & & & 2 & \\
\hline Monoporeia & & & & & & 3 \\
\hline Nassarius & & & 1 & & & \\
\hline Notomastus & & & 33 & & & \\
\hline Ophiactis & & & & 3 & 3 & 2 \\
\hline Ophiothrix & & 1 & & & & \\
\hline Paraonoipediae. & & & & 1 & & \\
\hline Phyllodoce & 1 & & & & & \\
\hline Poecilochaetus & 3 & & 2 & & & 1 \\
\hline Prionospio & 157 & 3 & 3 & 10 & & 4 \\
\hline Pulliela & & & 11 & & & \\
\hline Scina & & & & & 3 & \\
\hline Scoloplella & & 3 & 2 & & & \\
\hline Sigambra & & 5 & 34 & & & \\
\hline Sthenelanella & & 2 & & & 5 & \\
\hline Syllidia & & & & & 1 & \\
\hline Tanais & & 1 & & & & 3 \\
\hline Terebellidae. & & & & 1 & & \\
\hline Thyonidium & & & & & 3 & \\
\hline Thysanoessa & & & & & & 2 \\
\hline
\end{tabular}



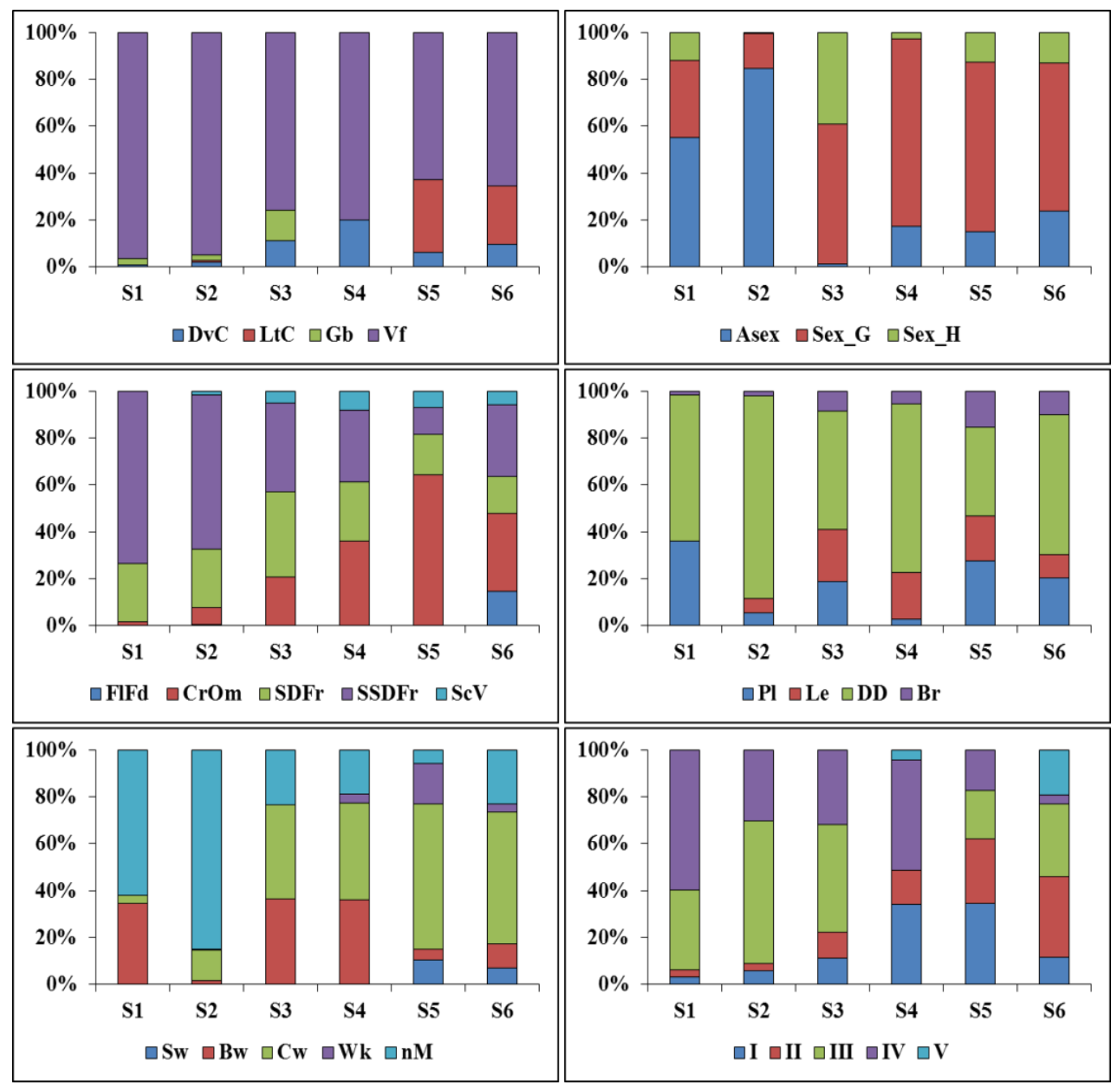

Figure 2. Distribution of traits for each station. Refer to Table 1 for labels

such as Capitellids, Cirratulids and Spionids are well-known to feed on detritus and absorb nutrients underneath sediment (Huang et al., 2012). They form tubes that transverse across sediment to absorb the nutrients, thus bearing the sub-surface deposit feeder (SSDFr) modality. These polychaetes are readily found in greater abundance in sediment with smaller size particle (Otegui et al., 2016). Guan et al. (2014) reported higher percentage of Sedentaria polychaetes in Sungai Pulai estuary which had less human intrusion. Mohamamad and Jalal (2018) also reported similar percentage of Sedentaria polychaetes in Pahang estuary, but unlike Sungai Pulai, it was the centre of human activity and the Errantia polychaetes were only found further off towns in Sungai Pahang. Smaller sediment size allowed easier propagation and settlement of Sedentaria polychaetes. Coupled with direct development trait, the taxon's larvae able to easily burrow into sediment and depend 
on nutrients, ultimately enable them to grow indiscriminately without problem, regardless the condition of the sediment, unpolluted or otherwise (Fadhullah \& Syakir, 2016).

Conversely, Surface deposit feeder (SDFr) modality encompassed all phyla in this study, but majority of these taxa associated with this trait were not entirely exclusive (fuzzy coding 3 ), but rather preferable (fuzzy coding 2) with only Thyodinium sea cucumber qualified as exclusive to this modality (González-Wangüemert et al., 2016). All polychaetes found in this study were associated with this modality (except Terebellid polychaete) but showed minor preference to this modality (fuzzy coding 1), including Sedentarian polychaetes as mentioned before. Brittle star, polychaete and gastropod taxa found in this study were commonly known for burrowing underneath sediment for wide range of purpose, from searching for food to protection from predators (Jumars et al., 2015; Roche et al. 2016). The idea of identifying macrobenthos' burrowing behaviour have long been investigated. Zorn et al. (2010) observed and reported movement of burrowing polychaetes in sediment. The polychaetes observed, were shown to be revolving throughout the sediment, forming tubes along their way, and occasionally returned to the same tubes to forage food particles that might come from surface above which dispersed into the sediment via bioturbation. Zorn et al. (2010) also noted these polychaetes' immediate burrowing response when detecting light intensity in the vicinity. Boos et al. (2010) focused similar behaviour, but towards brittle star, but unlike Zorn et al. (2010), variation of sizes in brittle star genera showed different burrowing strategies, in which smaller Ophiroids such as Ophiactis performed burrowing solely to avoid predation and deposit feeding, but larger genera done so to hunt for meiobenthos such as polychaetes and smaller arthropods.

Station 1 and 2 recorded the highest modality for non-motile (nM) in adult mobility trait and asexual (Asex) in reproduction technique trait. Similarly, Capitellid, Cirratulid and Spionid polychaetes contributed to higher taxa abundance in all stations especially in stations 1 and 2 (Faulwetter et al., 2017). These polychaetes are generally smaller-sized and prefer sediment with higher percentage of small-sized sediment for easier settlement and foraging (Figure 3) (Idris \& Arshad, 2013). A study by Wouters et al. (2018) in Southeastern coast of Brazil showed an increasing trend of Cirratulids, Capitellids and Spionid polychaetes across the continental slope, and highest intensity at flat beaches with lesser wave exposure and smaller-sized sediment grain in which the polychaetes would find easier to settle.

Lastly, for ecological group trait, second order opportunistic (IV) modality showed the highest modality in all stations, particularly in station 1. Station 2 and 3 showed highest modality for tolerant (III) modality. Borja et al. (2009) introduced AZTI Marine Biotic Index (AMBI) as an ecological index suitable to define marine taxa based on their availability in certain ecological area under specific circumstances. The group number in AMBI index determines which type of ecological area the taxa prefer to, or more readily available on. 


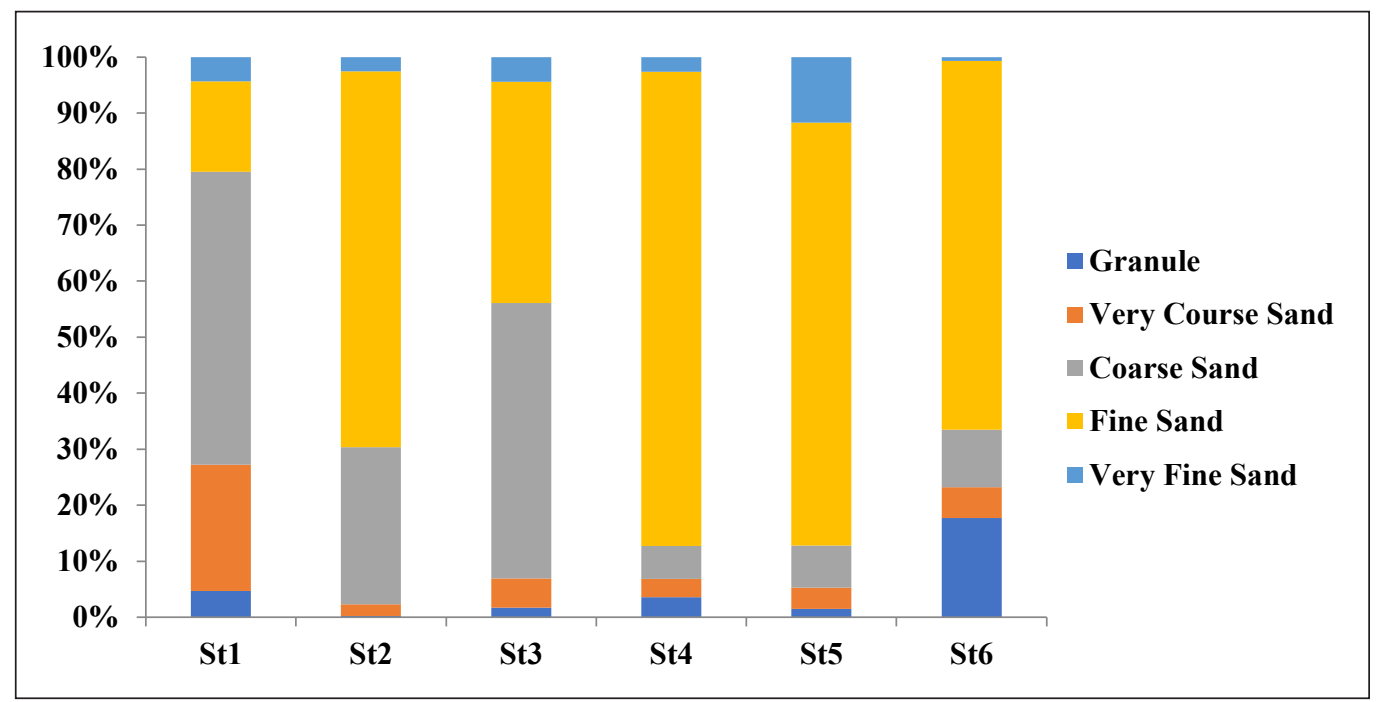

Figure 3. Particle size distribution for sediments in all stations in this study

For instance, Caulleriella polychaete in this study was classified as tolerant ecological group (III). This group indicates that the polychaete can be found in ecological zone where there are less ecological stresses (i.e., pollution problem). On the other hand, Cirriformia, another polychaete genus, was identified as second-order opportunistic group (IV), which means the genus was readily available in ecological zone that contained certain level of ecological stress (Galanidi et al., 2016). Notable study related to AMBI in Malaysia was conducted by Sany et al. (2015) toward benthic communities in Port Klang, focusing on assessing ecological quality of seafloor habitat. They measured the level of disturbance in the region by composing an assemblage of benthic taxa that had been ranked according to their respective ecological group (I to V), in which they concluded that the benthic communities in the area were overall still in tolerable condition due to lesser number of individuals in taxa ranked ecological I and II but higher number in taxa ranked III to V. Linares et al. (2018) assessed BTA toward benthic assemblages at a deactivated dam within Pandeiros River, Brazil. The study identified increase of non-native genera mollusks such as Asian Clam (Corbicula fluminea) and Red-Rimmed Melania Snail (Melanoides tuberculata), possibily originating from anthropogenic activities such as aquarium trade and ejection from removal of biofouling off boats into water. BTA assessment indicated that these taxa possessed scavenging traits, smaller bodies, and capable of tolerate changes of water quality in terms of $\mathrm{pH}$ and temperature (Ecological Group I).

\section{Assessment for Ecological and Functional Diversity}

Station 1 recorded the highest macrobenthos density (21000 ind. $/ \mathrm{m}^{2}$ ), while Station 4 showed the lowest $\left(1086.96\right.$ ind $\left./ \mathrm{m}^{2}\right)$. While station 3 accounted highest taxa number in 
all stations, station 5 accounted to highest in all ecological indices (Table 3). There was significant different in macrobenthos density between stations (one-way ANOVA, $p<0.05$ ).

Unlike the diversity index, functional diversity's purpose is to assess the variation and range of traits or characteristic of taxa within the ecosystem (Tilman, 2001). Higher FD indicates higher variations of traits shown by existing taxa within the area, i.e., chances of finding two different taxa with two different modalities from a trait become higher. $F D$ in body shape trait was highest in Station 5, followed by feeding mode trait and adult mobility in station 6 , reproductive technique trait in station 1 , larval development trait in station 5 and lastly ecological group trait in station 4 (Table 4).

The ecological group data was significantly differed between stations (one-way ANOVA, $P<0.05)$. All stations showed very large difference between all five modalities in ecological group trait. Large differences between AMBI ecological groups were also seen in other study such as Pilo et al. (2016), where there were distinct differences between benthic taxa sensitive, resistant, tolerant, and opportunistic in Tagus estuary, Portugal throughout the year. Pilo et al. (2016) noticed distinct changes of stress-tolerant ecological group and second-order opportunistic ecological group (IV) across the time.

Table 3

Ecological Indices for benthic communities in seafloor northwards of Port Klang

\begin{tabular}{ccccccc}
\hline Station & Taxa No. & Taxa Density & $\boldsymbol{H}^{\prime}$ & $\boldsymbol{J}^{\prime}$ & $\boldsymbol{D}$ & $\boldsymbol{D}_{\boldsymbol{m g}}$ \\
\hline St1 & 11 & 21000.00 & 1.61 & 0.45 & 0.76 & $\mathbf{1 . 6 2}$ \\
St2 & 10 & 7347.83 & 1.30 & 0.33 & 0.59 & $\mathbf{1 . 9 5}$ \\
St3 & 13 & 5043.48 & 1.98 & 0.56 & 0.81 & $\mathbf{2 . 5 2}$ \\
St4 & 8 & 1086.96 & 1.76 & 0.72 & 0.77 & $\mathbf{2 . 1 8}$ \\
St5 & $\mathbf{1 0}$ & $\mathbf{1 2 6 0 . 8 7}$ & $\mathbf{2 . 1 9}$ & $\mathbf{0 . 8 9}$ & $\mathbf{0 . 8 8}$ & $\mathbf{2 . 6 7}$ \\
St6 & 9 & 1130.43 & 2.06 & 0.87 & 0.86 & $\mathbf{2 . 4 6}$ \\
\hline
\end{tabular}

Table 4

Functional Diversity (FD) of traits in stations

\begin{tabular}{ccccccc}
\hline Station & $\begin{array}{c}\text { Body } \\
\text { Shape }\end{array}$ & $\begin{array}{c}\text { Feeding } \\
\text { Mode }\end{array}$ & $\begin{array}{c}\text { Adult } \\
\text { Mobility }\end{array}$ & $\begin{array}{c}\text { Reproductive } \\
\text { Technique }\end{array}$ & $\begin{array}{c}\text { Larval } \\
\text { Development }\end{array}$ & $\begin{array}{c}\text { Ecological } \\
\text { Group }\end{array}$ \\
\hline St1 & 0.05 & 0.18 & 0.60 & $\mathbf{0 . 6 1}$ & 0.20 & $\mathbf{0 . 5 6}$ \\
St2 & 0.11 & 0.22 & 0.49 & 0.40 & 0.19 & $\mathbf{0 . 5 2}$ \\
St3 & 0.31 & 0.23 & 0.44 & 0.38 & 0.59 & $\mathbf{0 . 6 9}$ \\
St4 & 0.30 & 0.65 & 0.56 & 0.48 & 0.60 & 0.73 \\
St5 & $\mathbf{0 . 5 6}$ & 0.57 & 0.55 & 0.50 & $\mathbf{0 . 6 3}$ & $\mathbf{0 . 7 2}$ \\
St6 & 0.57 & $\mathbf{0 . 6 6}$ & $\mathbf{0 . 7 0}$ & 0.45 & 0.60 & $\mathbf{0 . 7 0}$ \\
\hline
\end{tabular}




\section{Ecological Functioning of Benthic Communities in Seafloor Northwards of Pulau Indah, Klang with Regards to Environmental Parameters}

Principal component analysis and its eigenvalue showed ordination of modalities within all six stations in this study (Figure 4, Table 5). Station 1 was located at the mouth of Klang River and closest to Southpoint, one of the main ports in Port Klang. Station 1 was also attributed to multiple modalities, in which each of modalities were attributed to this station due to dominance of polychaetes and smaller percentage of gastropods (Table 6). Dominant polychaete genera in station 1 were Mediomastus (Family Capitellidae), Caulleriella and Cirriformia (Cirratulidae), and Prionospio (Spionidae). Besides possessing vermiform body shape, these polychaete genera generally live-in burrow and non-motile throughout their lifetime, deposit feeder, reproduce asexually (except Mediomastus) and rather possess direct development from larvae to adult form (Fauchald, 1977; Faulwetter et al., 2017; Mikac, 2015). Mediomastus and Caulleriella were tolerant ecological group (III) while Cirriformia and Prionospio were second-order opportunistic group (IV). Both Cirriformia and Prionospio polychaetes were known to be very common in sediment closer to industrial zones and sewage area, where the zone's sediment content might restrict movement and settlement of benthic taxa sensitive and tolerant towards ecological stresses (Musale \& Dessai, 2011). Rosli et al. (2016) showed similar report of higher abundance of Spionid, Capitellid and Cirratulid polychaetes at offshore Pekan, Pahang and Dungun, Terengganu coast and Kudat-Balambangan Island in Sabah, where smaller sediment size were more prevalent due to further proximity towards shoreline.

Station 2 was attributed towards globose modality $(\mathrm{Gb})$, and two reproductive techniques i.e., sexual gonochoric (Sex_G) and sexual hermaphrodite gonochoric (Sex_H). Station 2 was located between the eastern end of Pulau Indah and western end of mainland Klang and known to be one of the main routes for ships originating from Southpoint (Sany et al., 2014). Globose modality in this station was contributed by abundance of Cerithium snail, which was common in sediment with higher percentage of smaller-sized particles (Reid \& Claremont, 2014). Unlike in station 1, station 2 had both Errantian and Sedentarian polychaete groups, with most Errantian polychaetes such as Eunice (family Eunicidae), Scoloplella (family Orbiniidae), Ancistrosylis and Sigambra (family Pilargidae) and Sthenelanella (family Sigalionidae) all utilized sexual reproduction via mating between two sexes instead of hermaphrodite (Blake \& Arnosfsky, 1999).

Station 3 was attributed towards brooding modality $(\mathrm{Br})$ and sensitive ecological group (I). Both modalities were closely attributed to the gastropod taxa, which were mostly abundant in this station than others. Station 3 was located south to station 2, and closer towards the mouth of Langat River. Next, station 4, located between waterways from three ports (Southpoint, West Port and North Point), was attributed towards dorsallyventrally compressed $(\mathrm{DvC})$, carnivore-omnivore $(\mathrm{CrOm})$, scavenger $(\mathrm{ScV})$, crawler $(\mathrm{Cw})$, 
lecithotrophic (Le) and tolerant ecological group (II). Benthic community in station 4 comprised some non-polychaete taxa such as Ophiactis and Braychuran crab which might contribute to dorsally ventral compressed modality (Fujita \& Irimura, 2015). This body shape is exclusive in arthropods and echinoderms but also found in some polychaete taxa such as Micronepthys (family Nepthyidae) and Syllidia (family Eunicidae). All taxa found in this station were all exclusively predators and except Ophiactis which is scavenger (Faulwetter et al., 2017). Majority of polychaetes in this station was Errantian, and possess visible parapodia, and combined with other non-polychaete taxa Ophiactis brittle star and Paraonoipediae crab), contributed towards crawling modality in this study $(\mathrm{Ng}$, 2017). Errantian polychaete are common in intertidal zone or in seafloor closer to estuaries, rocky shore, and coral reefs (Gholizadeh, 2012: Polgar et al., 2015), in which both studies reported higher Errantian polychaetes at rocky shores nearby beaches of Penang, and former coral reef site in Jeram Beach, Selangor.

Next, station 5 was attributed to dorsal-ventrally-compressed body (DvC), scavenger $(\mathrm{ScV})$ and carnivore-omnivore $(\mathrm{CrOm})$ feeding behaviour, crawler $(\mathrm{Cw})$ and walker (Wk) adult mobility and lecithotrophic (Le) larval development modality. Station 5 was located between the west side of Pulau Indah, and the east side of Pulau Kelang. Majority of taxa found in this station included several Errantian polychaetes such as Eurythoe, Glycera,
Table 5

Eigenvalue scale for PCA analysis in Figure 3

\begin{tabular}{ccc}
\hline PC & Eigenvalue & \% variance \\
\hline $\mathbf{1}$ & 0.232 & $\mathbf{5 2 . 5 7 5}$ \\
$\mathbf{2}$ & 0.120 & $\mathbf{2 7 . 1 6 1}$ \\
$\mathbf{3}$ & 0.054 & $\mathbf{1 2 . 1 6 9}$ \\
$\mathbf{4}$ & 0.022 & $\mathbf{4 . 9 5 1}$ \\
$\mathbf{5}$ & 0.008 & $\mathbf{1 . 8 8 5}$ \\
$\mathbf{6}$ & 0.006 & $\mathbf{1 . 2 5 9}$ \\
\hline
\end{tabular}

Table 6

List of modalities attributed to the closest sampling stations in this study. (Refer to Table 1 for labels)

\begin{tabular}{|c|c|c|}
\hline Station & Trait & Modality \\
\hline \multirow[t]{6}{*}{ St1 } & Body Shape & Vf \\
\hline & Feeding Mode & SDFr, SSDFr \\
\hline & Adult Mobility & Bw, nM \\
\hline & $\begin{array}{l}\text { Reproductive } \\
\text { Technique }\end{array}$ & Asex \\
\hline & $\begin{array}{l}\text { Larval } \\
\text { Development }\end{array}$ & DD, PI \\
\hline & Ecological Group & III, IV \\
\hline St2 & Body Shape & Gb \\
\hline \multirow[t]{3}{*}{ St3 } & $\begin{array}{l}\text { Reproductive } \\
\text { Technique }\end{array}$ & Sex_G, Sex_H \\
\hline & Adult Mobility & $\mathrm{Br}$ \\
\hline & Ecological Group & I \\
\hline \multirow[t]{5}{*}{ St4 } & Body Shape & DvC \\
\hline & Feeding Mode & $\mathrm{CrOm}, \mathrm{ScV}$ \\
\hline & Adult Mobility & Cw \\
\hline & $\begin{array}{l}\text { Larval } \\
\text { Development }\end{array}$ & Le \\
\hline & Ecological Group & II \\
\hline \multirow[t]{4}{*}{ St5 } & Body Shape & DvC \\
\hline & Feeding Mode & $\mathrm{CrOm}, \mathrm{ScV}$ \\
\hline & Adult Mobility & $\mathbf{C w}, \mathbf{W k}$ \\
\hline & $\begin{array}{l}\text { Larval } \\
\text { Development }\end{array}$ & Le \\
\hline \multirow[t]{4}{*}{ St6 } & Body Shape & LtC \\
\hline & Feeding Mode & FIFd \\
\hline & Adult Mobility & Sw, Wk \\
\hline & Ecological Group & $\mathbf{V}$ \\
\hline
\end{tabular}




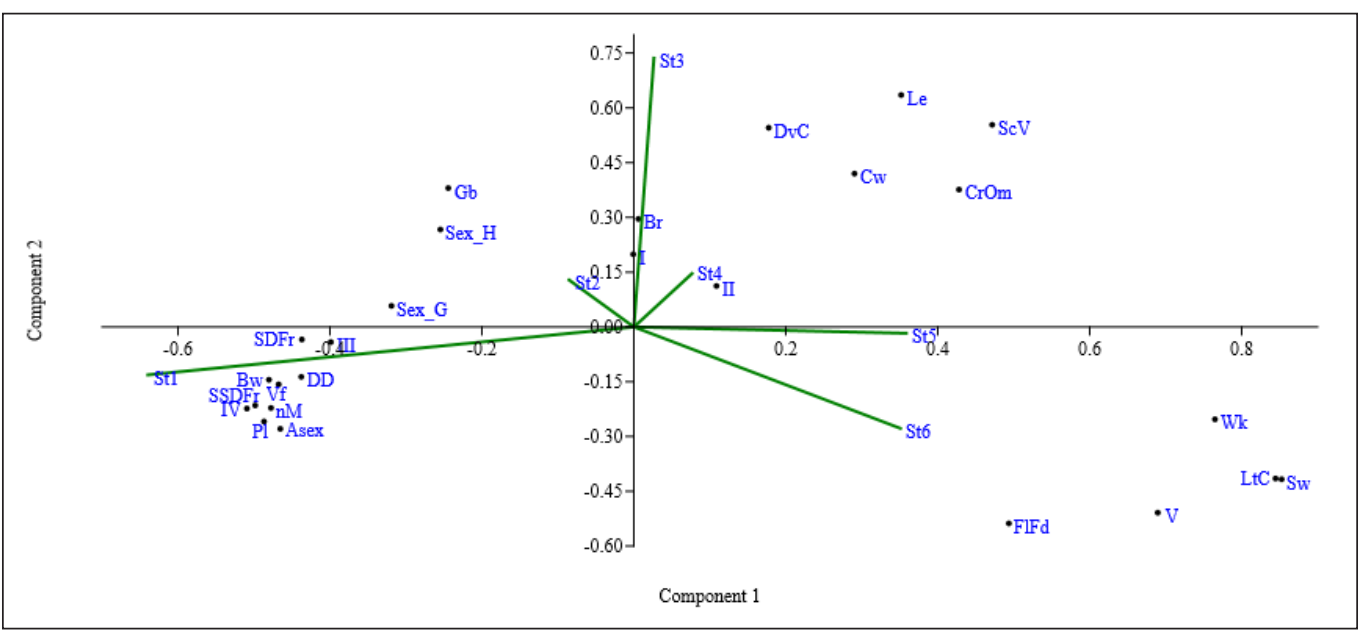

Figure 4. PCA ordination for all modalities on benthic communities in seafloor northwards of Pulau Indah, Klang

Goniada and Sthenalanella which were known to hunt for smaller benthos in sediment and known to propagate across sediment via crawling $(\mathrm{Cw})$ movement, except Ophiactis which contributed to scavenger (ScV) and walker (Wk) modality (Gammal et al., 2017).

Lastly, station 6 was attributed towards laterally compressed body shape (LtC), filter feeding (FlFd), swimmer (Sw), walker (Wk) and first-order opportunistic ecological group (V). Station 6 was also located between Pulau Indah and Pulau Kelang, but unlike station 5 , this station was closer to several small estuaries from Pulau Kelang. Apart from smaller number of taxa $(n=9)$, individual numbers of benthic taxa were also small. Population of benthic community in this station contained almost equal number of polychaete and nonpolychaete genera. Both laterally compressed body shape, filter feeding, and swimmer modality were contributed by amphipod Monoporeia and tanaid Tanais, and like station 5, walker modality was contributed by brittle star Ophiactis (Gammal et al., 2017). Previous study by Norhayati et al. (2009) showed higher abundance of benthic community inhabiting mangrove areas of Pulau Kelang, which might explain the splinter of these genera in this region. Brittle star Ophiactis and non-Brachyura arthropods (amphipod and tanaid) were commonly found in Malaysian estuaries and intertidals with shallower depth (less than 20 m), as shown in reports by Fujita and Irimura (2015) and Yap et al. (2020) for brittle star and amphipods, respectively.

Pearson Correlation Analysis indicated that very fine sand $(0.063 \mathrm{~mm})$ showed significant correlation towards laterally compressed (LtC) and swimmer (Sw) modality (Table 7). Laterally compressed body shape is common for arthropods with streamlined body such as amphipods and copepods. This body shape enables these taxa to manoeuvre both water current and sediment. Smaller Arthropod taxa such as Monoporeia, Thysanoessa 
Table 7

Pearson Correlation Table between trait modalities and environmental parameters assessed in this study. Refer to Table 1 for labels. * indicates significant correlation at 0.01 (two-tailed) and ** indicates significant correlation at 0.05 (two-tailed)

\begin{tabular}{|c|c|c|c|c|c|c|c|c|}
\hline & Salinity & Depth & TOC & VFS & FS & $\mathrm{CS}$ & VCS & $\mathrm{G}$ \\
\hline $\mathrm{DvC}$ & -0.15 & -0.33 & -0.07 & -0.46 & -0.08 & 0.62 & -0.32 & 0.10 \\
\hline $\mathrm{LtC}$ & 0.50 & $0.93^{\text {** }}$ & 0.17 & $0.86^{*}$ & -0.03 & -0.62 & 0.38 & -0.49 \\
\hline $\mathrm{Gb}$ & -0.58 & -0.37 & 0.29 & -0.47 & -0.41 & $0.98^{* *}$ & -0.20 & 0.37 \\
\hline Vf & -0.77 & -0.46 & 0.38 & -0.41 & -0.42 & 0.76 & -0.03 & 0.60 \\
\hline $\mathrm{FlFd}$ & 0.70 & 0.50 & 0.78 & 0.75 & -0.71 & -0.23 & $0.96^{* *}$ & -0.37 \\
\hline $\mathrm{CrOm}$ & -0.09 & 0.23 & -0.32 & -0.12 & 0.29 & 0.22 & -0.51 & -0.35 \\
\hline SDFr & -0.78 & -0.48 & 0.37 & -0.46 & -0.43 & $.851^{*}$ & -0.08 & 0.59 \\
\hline SSDFr & -0.75 & -0.45 & 0.38 & -0.39 & -0.42 & 0.73 & -0.01 & 0.61 \\
\hline $\mathrm{ScV}$ & 0.12 & -0.03 & -0.30 & -0.25 & 0.24 & 0.23 & -0.41 & -0.42 \\
\hline Sw & 0.46 & $0.93^{* *}$ & 0.14 & $0.84^{*}$ & -0.01 & -0.60 & 0.35 & -0.40 \\
\hline $\mathrm{Bw}$ & -0.68 & -0.37 & 0.42 & -0.31 & -0.51 & 0.76 & 0.05 & 0.76 \\
\hline $\mathrm{Cw}$ & -0.08 & 0.03 & 0.08 & -0.20 & -0.16 & 0.61 & -0.24 & -0.28 \\
\hline Wk & 0.12 & 0.64 & -0.34 & 0.46 & 0.44 & -0.62 & -0.15 & -0.21 \\
\hline $\mathrm{nM}$ & -0.75 & -0.48 & 0.34 & -0.42 & -0.36 & 0.69 & -0.04 & 0.50 \\
\hline Asex & -0.74 & -0.47 & 0.32 & -0.41 & -0.32 & 0.62 & -0.04 & 0.46 \\
\hline Sex_G & -0.70 & -0.36 & 0.41 & -0.36 & -0.51 & $0.87^{*}$ & -0.03 & 0.69 \\
\hline Sex_H & -0.54 & -0.26 & 0.39 & -0.32 & -0.51 & $0.92^{*}$ & -0.06 & 0.53 \\
\hline $\mathrm{Pl}$ & -0.69 & -0.32 & 0.44 & -0.25 & -0.50 & 0.69 & 0.08 & 0.73 \\
\hline $\mathrm{Lc}$ & -0.05 & -0.12 & -0.21 & -0.35 & 0.13 & 0.44 & -0.43 & -0.31 \\
\hline DD & -0.77 & -0.51 & 0.34 & -0.46 & -0.37 & 0.75 & -0.07 & 0.51 \\
\hline $\mathrm{Br}$ & -0.56 & -0.10 & 0.29 & -0.28 & -0.38 & $0.89^{*}$ & -0.20 & 0.31 \\
\hline I & $-0.94^{* *}$ & -0.49 & -0.10 & -0.66 & 0.01 & 0.81 & -0.57 & 0.57 \\
\hline II & -0.31 & 0.17 & 0.66 & 0.11 & -0.73 & 0.78 & 0.25 & 0.31 \\
\hline III & -0.77 & -0.50 & 0.33 & -0.49 & -0.36 & $0.81^{*}$ & -0.12 & 0.38 \\
\hline IV & -0.74 & -0.42 & 0.39 & -0.35 & -0.44 & 0.72 & 0.01 & 0.70 \\
\hline V & $0.88^{*}$ & 0.51 & 0.59 & 0.78 & -0.54 & -0.46 & $0.92^{*}$ & -0.32 \\
\hline
\end{tabular}

and Tanais were common at seafloor rather than the surface, and preferred sediment with smaller sediment size, in which they utilize the sediments' nature for foraging detritus via filter feeding (Navarro-Barranco \& Hughes, 2015). The Tanaid shrimp (Tanais), Pontoporeiid amphipod (Monoporeia), and krill (Thysanoessa) were common in Malaysian water and were in higher abundance in nutrient-rich estuaries such as Pulau Kelang, Selangor (Norhayati et al., 2009) and Mengabang Telipot river, Terengganu (Ramli et al., 2018).

Coarse sand $(0.5 \mathrm{~mm})$ was correlated towards the following modality: globose $(\mathrm{Gb})$, sexual gonocoric (Sex_G), sexual hermaphrodite (Sex_H), brooding (Br) and tolerant ecological group (III). Coarse sand $(0.5 \mathrm{~mm})$ is often considered as suitable substrate 
for settlement of macro-sized benthic taxa such as gastropods and arthropods, and even Errantian polychaetes. This includes suitability for procreation of offspring for the taxa by general. Bannister et al. (2012) reported noticeable changes of benthic larval spawning across the Great Barrier Reef, Australia and this fluctuation was attributed to particle size distribution, with coarse sand $(0.5 \mathrm{~mm})$ as suitable substrate for macrobenthic taxa larva to settle and develop. Coarse sand $(0.5 \mathrm{~mm})$ also considered as suitable substrate for gastropods, as was shown in Genner and Michel (2003) where their study established link between particle size distributions and sea snail's assemblage in Cape Maclear, Malawi. They found that habitat with higher percentage of sediment size less than $0.5 \mathrm{~mm}$ contained more sea snails (Genner \& Michel, 2003).

\section{CONCLUSION}

This study concludes that vermiform body shape, direct larval development, deposit feeder, non-motile, asexually reproductive and second-order opportunistic ecological group were the most dominant sub-traits in this study. While station 1 has the highest taxa density, station 5 is most diverse. Functional diversity showed that reproductive technique trait was more diverse in station 1 , followed by ecological group in station 4 , body shape and larval development in station 5, and lastly feeding mode and adult mobility in station 6 . PCA analysis indicated stations 1 and 4 attributed majority of modalities assessed in this study, but none in station 5. Correlation analyses showed multiple modalities strongly correlated towards size particle distribution, more specifically very fine sediment $(0.063$ $\mathrm{mm})$ and coarse sediment $(0.5 \mathrm{~mm})$, and depth.

Unlike other countries, BTA study is still a new field in Malaysia. Therefore, the data linked to BTA regarding benthic population in Malaysian water is very inadequate and lacking. The study could a be a good starting point for the use of BTA, or at least could serve as a suitable and adequate comparative study for other areas in Malaysia such as in coral reefs, mangrove biotopes and even waters nearby industrial zones like this study. In similar fashion as identifying suitable occupation for human population in an area for a certain period of situations and time, if conducted more frequently and comprehensively, BTA can serve as time capsule for us to observe certain changes in benthic community in Malaysian's water over time.

\section{ACKNOWLEDGEMENT}

We sincerely thank Mr. Zuhaimi from the Marine Science Program, Universiti Kebangsaan Malaysia for his dedicated efforts on sample collection. This work was funded by Fundamental Research Grant, Ministry of Higher Education, Malaysia (project no. FRGS/1/2017/STG03/UKM/02/5). 


\section{REFERENCES}

Baharuddin, N., Basri, N. B., \& Syawal, N. H. (2018). Marine gastropods (Gastropoda; Mollusca) diversity and distribution on intertidal rocky shores of Terengganu, Peninsular Malaysia. Bioflux, 11(4), 1144-1154.

Bannister, R. J., Battershill, C. N., \& de Nys, R. (2012). Suspended sediment grain size and mineralogy across the continental shelf of the great barrier reef: Impacts on the physiology of a coral reef sponge. Continental Shelf Research, 32, 86-95. https://doi.org/10.1016/j.csr.2011.10.018.

Blake, J. A., \& Arnofsky, P. L. (1999). Reproduction and larval development of the Spioniform polychaeta with application to systematics and phylogeny. Hydrobiologia, 402, 57-106. https://doi. org/10.1023/A:1003784324125.

Bolam, S. G., Garcia, C., Eggleton, J., Kenny, A. J., Buhl-Mortensen, L., Gonzalez-Mirelis, G., van Kooten, T., Dinesen, G., Hansen, J., Hiddink, J. G., Sciberras, M., Smith, C., Papadopoulou, N., Gumus, A., Van Hoey, G., Eigaard, O. R., Bastardie, F., \& Rijnsdorp, A. D. (2017). Differences in biological traits composition of benthic assemblages between unimpacted habitats. Marine Environmental Research, 126, 1-13. https://doi.org/10.1016/j.marenvres.2017.01.004.

Bolam, S. G., McIlwaine, P. S. O., \& Garcia, C. (2016). Application of biological traits to further our understanding of the impacts of dredged material disposal on benthic assemblages. Marine Pollution Bulletin, 105(1), 180-192. https://doi.org/10.1016/j.marpolbul.2016.02.031.

Boos, K., Gutow, L., Mundry, R., \& Franke, H. (2010). Sediment preference and burrowing behaviour in the sympatric brittlestars Ophiura albida (Forbes, 1839) and Ophiura ophiura (Linnaeus, 1738) (Ophiuroidea, Echinodermata). Journal of Experimental Marine Biology and Ecology, 393(2010), 176-181. https://doi. org/10.1016/j.jembe.2010.07.021.

Borja, A., Muxika, I., \& Rodríguez, J. G. (2009). Paradigmatic responses of marine benthic communities to different anthropogenic pressures, using M-AMBI, within the European water framework directive. Marine Ecology, 30(2), 214-227. https://doi.org/10.1111/j.1439-0485.2008.00272.x.

Dell, A. I., Pawar, S., \& Savage, V. M. (2011). Systematic variation in the temperature dependence of physiological and ecological traits. Proceedings of the National Academy of Sciences of the United States of America, 26, 10591-10596. https://doi.org/10.1073/pnas.1015178108.

Fadhullah, W., \& Syakir, M. I. (2016). Polychaetes as ecosystem engineers: Agents of sustainable technologies. In M. I. Ahmad, M. Ismail \& S. Riffat (Eds.), Renewable energy and sustainable technologies for building and environmental applications (pp. 137-150). Springer. https://doi.org/10.1007/978-3-319-31840-0_8.

Fauchald, K. (1977). The polychaete worms: Definitions and keys to the orders, family and genera. Natural History Museum of Los Angeles County, California.

Faulwetter, S., Simboura, N., Katsiaras, N., Chatzigeorgiou, G., \& Arvanitidis, C. (2017). Polychaetes of Greece: An updated and annotated checklist. Biodiversity Data Journal, 2017(5), 1-220. https://doi. org/10.3897/BDJ.5.e20997.

Fujita, T., \& Irimura, S. (2015). Preliminary list of ophiuroids (Echinodermata: Ophiuroidea) collected from the Johor Straits, Singapore. Raffles Bulletin of Zoology, 31, 264-272. 
Galanidi, M., Kaboglu, G., \& Bizsel, K. C. (2016). Predicting the composition of polychaete assemblages in the Aegean coast of Turkey. Frontiers in Marine Science, 3(8), 1-14. https://doi.org/10.3389/ fmars.2016.00154.

Gammal, J., Norkko, J., Pilditch, C. A., \& Norkko, A. (2017). Coastal hypoxia and the importance of Benthic macrofauna communities for ecosystem functioning. Estuaries and Coasts, 40, 457-468. https://doi. org/10.1007/s12237-016-0152-7.

Genner, M. J., \& Michel, E. (2003). Fine-scale habitat associations of soft-sediment gastropods at Cape Maclear, Lake Malawi. Journal of Molluscan Studies, 69(4), 325-328. https://doi.org/10.1093/mollus/69.4.325.

Gergs, R., \& Rothhaupt, K. O. (2015). Invasive species as driving factors for the structure of benthic communities in Lake Constance, Germany. Hydrobiologia, 746(1), 245-254. https://doi.org/10.1007/ s10750-014-1931-4.

Gholizadeh, M. (2012). Effects of environmental factors on polychaete assemblage in Penang National Park, Malaysia, World Academy of Science, Engineering and Technology, 72, 669-672.

González-Wangüemert, M., Valente, S., Henriques, F., Domínguez-Godino, J. A., \& Serrão, E. A. (2016). Setting preliminary biometric baselines for new target sea cucumbers species of the NE Atlantic and Mediterranean fisheries. Fisheries Research, 179, 57-66. https://doi.org/10.1016/j.fishres.2016.02.008.

Guan, W. S., Lee, D. M., Abd Ghaffar, M., Md Ali, M., \& Che Cob, Z. (2014). Macrobenthos composition, distribution and abundance within Sungai Pulai estuary, Johor, Malaysia. In AIP Conferences Proceedings (pp 591-596). American Institute of Physics. https://doi.org/10.1063/1.4895269.

Hanamura, Y., Siow, R., \& Chee, P. E. (2008). Reproductive biology and seasonality of the Indo-Australasian mysid Mesopodopsis orientalis (Crustacea: Mysida) in a tropical mangrove estuary, Malaysia. Estuarine, Coastal and Shelf Science, 77(3), 467-474. https://doi.org/10.1016/j.ecss.2007.10.015.

Hou, Y., Kong, F., Li, Y., Xi, M., \& Yu, Z. (2020). Key factors of the studies on benthic macroinvertebrate in coastal wetlands: Methods and biodiversity. Ecohydrology and Hydrobiology, 20(3), 424-436. https:// doi.org/10.1016/j.ecohyd.2020.02.004

Huang, Y. C. A., Huang, S. C., Hsieh, H. J., Meng, P. J., \& Chen, C. A. (2012). Changes in sedimentation, sediment characteristics, and benthic macrofaunal assemblages around marine cage culture under seasonal monsoon scales in a shallow-water bay in Taiwan. Journal of Experimental Marine Biology and Ecology, 422, 55-63. https://doi.org/10.1016/j.jembe.2012.04.008.

Hussin, W. M. R. W. (2014). Marine fish farming in Bidong Island, Malaysia and its implications on benthic community structure and functional diversity. Aquaculture, Aquarium, Conservation \& Legislation, 7(6), $431-440$.

Idris, I., \& Arshad, A. (2013). Checklist of polychaetous annelids in Malaysia with redescription of two commercially exploited species. Asian Journal of Animal and Veterinary Advances, 8(3), 409-436. https:// doi.org/10.3923/ajava.2013.409.436.

Jumars, P. A., Dorgan, K. M., \& Lindsay, S. M. (2015). Diet of worms emended: An update of polychaete feeding guilds. Annual Review of Marine Science, 7, 497-520. https://doi.org/10.1146/annurevmarine-010814-020007. 
Korte, A., \& Ashley, F. (2013). The advantages and limitations of trait analysis with GWAS: A review selffertilisation makes Arabidopsis particularly well suited to GWAS. Plant Methods, 9, 29. https://doi. org/10.1186/1746-4811-9-29.

Lepš, J., de Bello, F., Lavorel, S., \& Berman, S. (2006). Quantifying and interpreting functional diversity of natural communities: Practical considerations matter. Preslia, 78, 361-374.

Linares, M. S., Callisto, M., \& Marques, J. C. (2018). Thermodynamic based indicators illustrate how a run-of-river impoundment in neotropical savanna attracts invasive species and alters the benthic macroinvertebrate assemblages' complexity. Ecological Indicators, 88, 181-189. https://doi.org/10.1016/j. ecolind.2018.01.040.

Linden, P., Patrício, J., Marchini, A., Cid, N., Neto, J. M., \& Marques, J. C. (2012). A biological trait approach to assess the functional composition of subtidal benthic communities in an estuarine ecosystem. Ecological Indicators, 20, 121-133. https://doi.org/10.1016/j.ecolind.2012.02.004.

Lomovasky, B. J., Firstater, F. N., Salazar, A. G., Mendo, J., \& Iribarne, O. O. (2011). Macro benthic community assemblage before and after the 2007 tsunami and earthquake at Paracas Bay, Peru. Journal of Sea Research, 65(2), 205-212. https://doi.org/10.1016/j.seares.2010.10.002.

Mikac, B. (2015). A sea of worms: polychaete checklist of the Adriatic Sea. Zootaxa, 3943(1), 1-172. https:// doi.org/10.11646/zootaxa.3943.1.1.

Mohamamad, A., \& Jalal, K. (2018). Macrobenthic diversity and community composition in Pahang Estuary, Malaysia. Journal of Coastal Research, 82(4), 206-211.

Musale, A. S., \& Desai, D. V. (2011). Distribution and abundance of macrobenthic polychaetes along the South Indian coast. Environmental Monitoring and Assessment, 178, 423-436. https://doi.org/10.1007/ s10661-010-1701-3.

Navarro-Barranco, C., \& Hughes, L. Z. (2015). Effects of light pollution on the emergent fauna of shallow marine ecosystems: Amphipods as a case study. Marine Pollution Bulletin, 94(1-2), 235-240.

Ng, P. K. L. (2017). On the identities of the highland vampire crabs, Geosesarma foxi (Kemp, 1918) and G. serenei Ng, 1986, with description of a new phytotelmic species from Penang, Peninsular Malaysia (Crustacea: Decapoda: Brachyura: Sesarmidae). Raffles Bulletin of Zoology, 65, 226-242.

Ng, P. K. L., \& Davie, P. J. F. (2002). A checklist of the Brachyuran crabs of Phuket and Western Thailand. Phuket Marine Biological Center Special Publication, 23(2), 369-384.

Norhayati, A., Shukor, M. N., Juliana, S., \& Wan, J. W. A. (2009). Mangrove flora and fauna of Klang islands mangrove forest reserves, Selangor, Malaysia. Malaysian Journal of Science, 28(3), 275-288. https://doi. org/10.22452/mjs.vol28no3.6.

Ong, J. Y., \& Wong, H. P. (2015). Sea cucumbers (Echinodermata: Holothuroidea) from the Johor Straits, Singapore. Raffles Bulletin of Zoology, 31, 273-291.

Otegui, M. B. P., Brauko, K. M., \& Pagliosa, P. R. (2016). Matching ecological functioning with polychaete morphology: Consistency patterns along sedimentary habitats. Journal of Sea Research, 114, 13-21. https://doi.org/10.1016/j.seares.2016.05.001. 
Padron, M., \& Guizien, K. (2016). Modelling the effect of demographic traits and connectivity on the genetic structuration of marine metapopulations of sedentary benthic invertebrates Mariana. ICES Journal of Marine Science, 73(7), 1935-1945.

Paganelli, D., Marchini, A., \& Occhipinti-Ambrogi, A. (2012). Functional structure of marine benthic assemblages using biological traits analysis (BTA): A study along the Emilia-Romagna coastline (Italy, North-West Adriatic Sea). Estuarine, Coastal and Shelf Science, 96(1), 245-256. https://doi.org/10.1016/j. ecss.2011.11.014.

Piló, D., Ben-Hamadou, R., Pereira, F., Carriço, A., Pereira, P., Corzo, A., Gaspar, M. B., \& Carvalho, S. (2016). How functional traits of estuarine macrobenthic assemblages respond to metal contamination? Ecological Indicators, 71, 645-659. https://doi.org/10.1016/j.ecolind.2016.07.019.

Polgar, G., Nishi, E., Idris, I., \& Glasby, C. J. (2015). Tropical polychaete community and reef dynamics: Insights from a Malayan Sabellaria (Annelida: Sabellariidae) reef. Raffles Bulletin of Zoology, 63, 401-417.

Ramli, R., Kassim, Z., \& Roslani, M. A. (2018). Meiofaunal responses to azoic sediment in a sandbar-regulated estuary in the East Coast of Peninsular Malaysia. In Proceedings of the Second International Conference on the Future of ASEAN (ICoFA) 2017-Volume 2 (pp. 899-908). Springer. https://doi.org/10.1007/978981-10-8471-3_89.

Reid, D. G., \& Claremont, M. (2014). The genus Cerithideopsis Thiele, 1929 (Gastropoda: Potamididae) in the Indo-West Pacific region. Zootaxa, 3779(1), 61-80. https://doi.org/10.11646/zootaxa.3779.1.8.

Roche, K. R., Aubeneau, A. F., Min, W. X., Aquino, T. C., Bolster, D., \& Packman, A. I. (2016). An integrated experimental and modelling approach to predict sediment mixing from benthic burrowing behaviour. Environmental Science \& Technology, 50(18), 10047-10054. https://doi.org/10.1021/acs.est.6b01704.

Rosli, N. S., Yahya, N., Arifin, I., \& Bachok, Z. (2016). Diversity of Polychaeta (Annelida) in the continental shelf of Southern China Sea. Middle-East Journal of Scientific Research, 24(6), 2086-2092. https://doi. org/10.5829/idosi.mejsr.2016.24.06.23650.

Sany, S. B. T., Hashim, R., Salleh, A., Rezayi, M., \& Safari, O. (2015). Ecological quality assessment based on microbenthic assemblages indices along West Port, Malaysia coast. Environmental Earth Science, 74(2), 1331-1341. https://doi.org/10.1007/s12665-015-4122-3.

Sany, S. B. T., Rezayi, M., Hashim, R., Salleh, A., \& Safari, O. (2014). Diversity and distribution of benthic invertebrates in the West Port, Malaysia. International Journal of Environmental, Ecological, Geological and Mining Engineering, 8(7), 458-461.

Tilman, D. (2001). Functional diversity. Encyclopedia of Biodiversity, 3(1), 109-120.

Verberk, W. C. E. P., Van Noordwijk, C. G. E., \& Hildrew, A. G. (2013). Delivering on a promise: Integrating species traits to transform descriptive community ecology into a predictive science. Freshwater Science, 32(2), 531-547. https://doi.org/10.1899/12-092.1.

Widdows, J., Brown, S., Brinsley, M. D., Salkeld, P. N., \& Elliott, M. (2000). Temporal changes in intertidal sediment erodability: Influence of biological and climatic factors. Continental Shelf Research, 20(10-11), 1275-1289. https://doi.org/10.1016/S0278-4343(00)00023-6. 
Wouters, J. M., Gusmao, J. B., Mattos, G., \& Lana, P. (2018). Polychaete functional diversity in shallow habitats: Shelter from the storm. Journal of Sea Research, 135(2018), 18-30. https://doi.org/10.1016/j. seares.2018.02.005.

Xu, Y., Stoeck, T., Forster, D., Ma, Z., Zhang, L., \& Fan, X. (2018). Environmental status assessment using biological traits analyses and functional diversity indices of benthic ciliate communities. Marine Pollution Bulletin, 131, 646-654. https://doi.org/10.1016/j.marpolbul.2018.04.064.

Yap, T. K., Saleh, E., \& Gallagher, J. B. (2020). Impacts of associated fauna on seagrass during the conditioning period in husbandry tanks: Gaya Island, Sabah, Malaysia case study. Transactions on Science and Technology, 7(2), 50-57.

Zhong, X. X., Xu, G. J., Mamun, A. A., Warren, A., \& Xu, H. L. (2018). Identifying bioindicators across traittaxon space for assessing water quality in marine environments. Marine Pollution Bulletin, 131, 565-571. https://doi.org/10.1016/j.marpolbul.2018.04.044.

Zorn, M. E., Gingras, M. K., \& Pemberton, S. G. (2010). Variation in burrow-wall micromorphoogies of select intertidal invertebrates along the Pacific Northwest Coast, USA: Behavioural and diagenetic implications. Palaios, 25, 59-72. https://doi.org/10.2110/palo.2009.p09-026r. 